\title{
PENGUKURAN KEMAMPUAN MANAJERIAL KARYAWAN DENGAN METODE METODE ANALYTICAL HIERARCHY PROCESS (AHP)
}

\author{
Suzana Dewi ${ }^{1 *}$, Suryo Atmojo ${ }^{2}$, Muharom ${ }^{3}$, Krisnadhi Hariyanto ${ }^{4}$ \\ ${ }^{1}$ Teknik Informatika, Universitas Wijaya Putra \\ ${ }^{2}$ Teknik Informatika, Universitas Wijaya Putra \\ ${ }^{3}$ Teknik Mesin, Universitas Wijaya Putra \\ ${ }^{4}$ Teknik Industri, Universitas Wijaya Putra \\ *Email: suzanadewi@uwp.ac.id
}

\begin{abstract}
Abstrak
Sangatlah penting untuk mengelola sumber daya manusia yang memiliki keahlian dan keterampilan dalam menyelesaikan suatu pekerjaan yang diukur berdasarkan prestasi kerja seorang karyawan. Pada saat ini para pemimpin puncak perusahaan PT. Surya Mas Megah Steel yang berlokasi di Surabaya akan mengukur kemampuan karyawannya dalam menyelesaikan suatu pekerjaannya. Permasalahan yang dihadapi oleh pihak manajemen saat ini adalah tidak adanya besaran nilai kemampuan manajerial yang diukur berdasarkan prestasi kerja seorang karyawan. Pihak manajemen mempunyai tujuan untuk mengelola sumber daya manusia berdasarkan waktu dan anggaran yang sifatnya terbatas. Pengelolaan sumber daya tersebut dinilai menggunakan metoda Analytical Hierarchy Process (AHP) yang didasarkan pada kemampuan manajerial untuk menilai prestasi setiap karyawannya. Tahapan yang terpenting didalam pengukuran prestasi kerja karyawan adalah menilai prestasi kinerja karyawan dalam menyelesaikan pekerjaannya menggunakan metoda AHP dengan cara mencari bobot setiap factor dan memberikan peringkat berdasarkan bobot kepentingannya. Kriteria yang dihasilkan terdiri dari aspek kemampuan manajerial berupa faktor kehadiran, kehandalan dan pengetahuan. Aspek manajerial memegang peranan yang cukup penting untuk menentukan keberhasilan karyawan. Dari hasil penelitian didapatkan indikator kemampuan manajerial terhadap faktor pendukung dari masing-masing kriteria kehadiran $(0,6615)$, pengetahuan $(0,1705)$ dan kerjasama $(0,1679)$. Nilai skor total rata-rata ke 27 responden yang didapatkan dari aspek manajerial terhadap faktor kehadiran, pengetahuan dan kerjasama sebesar 4.389. Nilai prestasi kerja standar yang diinginkan sebesar 3.389, dimana nilai skor total lebih tinggi dari nilai prestasi. Sebagai hasil penelitian dari kemampuan manajerial terhadap faktor kehadiran, pengetahuan dan kerjasama secara analisis berdampak langsung terhadap peningkatan nilai prestasi kerja rata-rata $33.117 \%$.
\end{abstract}

Keyword : Analytical Hierarchy Process (AHP), Kemampuan Manajerial, Kehadiran,, Kehandalan, Pengetahuan.

\section{PENDAHULUAN}

Sebuah organisasi tidak dapat berkembang dengan baik apabila ada keterbatasan dari waktu dan biaya. Keterbatasan waktu dan biaya sangat berpengaruh untuk mengubah tujuan organisasi. Tujuan organisasi berdampak langsung terhadap kemampuan manajerial dalam mengelola sumber daya yang ada. Ketidakmampuan sebuah organisasi ditentukan oleh kemampuan manajerial dalam mengelola sumber daya yang ada terlebih lagi untuk menilai kinerja setiap karyawan dalam menyelesaikan pekerjaannya. Kondisi tersebut juga terjadi pada PT. Surya Mas Megah Steel yang bergerak dibidang produksi pipa baja bermutu tinggi. Selama ini perusahaan tidak menilai karyawannya dalam menyelesaikan pekerjaannya. Penilaian yang sekarang ini hanya sebatas pada jumlah produk yang dihasilkan oleh setiap karyawan tanpa mempertimbangkan nilai prestasi kerja yang 
diterima oleh setiap karyawannya. Kondisi saat ini timbul karena belum diukurnya nilai kinerja setiap karyawan. Karyawan yang tidak memiliki prestasi kerja mendapatkan nilai yang sama dengan karyawan yang mempunyai kinerja yang baik ataupun tinggi. Keadaan ini sangat tidak menguntungkan bagi karyawan yang menghasilkan output produksi diatas ratarata atau bahkan melebihi target yang telah ditentukan. Dalam menanggulangi hal tersebut pihak perusahaan harus mencari jalan atau solusi untuk memecahkan permasalahan tersebut. Solusi terbaik yang harus dilakukan oleh pihak perusahaan adalah menentukan penilaian yang efektif dengan cara menggunakan metoda analytical hierarchy process (AHP). Penilaian dengan menggunakan AHP ini akan membantu perusahaan untuk menentukan nilai kenerja karyawan yang harus diterima oleh setiap karyawan berdasarkan kemampuan manajerial yang berhubungan langsung dengan faktor kehadiran, kerjasama dan pengetahuan dari karyawannya. Ketiga faktor tersebut merupakan komponen utama untuk menentukan kemampuan manajerial karyawannya yang diukur berdasarkan nilai prestasi kerjanya. Metoda Analytical Hierarchy Process ini merupakan pengukuran yang sesuai dan tepat untuk menyelesaikan permasalahan yang dihadapi perusahaan dalam menentukan nilai prestasi kerja karyawannya. Pengukuran dengan menggunakan Analytical Hierarchy Process ini membantu perusahaan dalam menentukan besarnya nilai kinerja karyawan yang harus diterima oleh karyawannya dalam menyelesaikan ouput produksinya.

\section{METODE PENELITIAN}

Pemilihan Elemen Ukur dari kemampuan manajerial yang disebutkan dalam penelitian ini dikonfigurasi dengan faktor kehadiran, kerjasama dan pengetahuan. Metodologi pengambilan keputusan AHP yang dimaksudkan untuk mengidentifikasi kemampuan manajerial terhadap faktor kehadiran, kehandalan dan pengetahuan melalui penilaian perbandingan berpasangan dari elemen yang membentuk hierarki pengambilan keputusan. Ada empat tahapan proses / empat langkah dalam pengaturan hierarki berupa perbandingan elemen berpasangan, penilaian bobot, analisis konsistensi dan sintesis dari bobot relatif. Langkah 1: Pengaturan hierarki.

Hirarki dikonfigurasi dengan mengklasifikasikan item yang terkait dengan pengambilan keputusan dalam penyusunan struktur bagian atas dengan tujuan untuk pengambilan keputusan dan dibagian bawahannya yang terdiri dari unsur-unsur yang mempengaruhi pengambilan keputusan.

Langkah 2 : Penentuan bobot kriteria yang berhubungan dengan kemampuan manajerial berupa faktor kehadiran, kerjasama dan pengetahuan.

Langkah 3: Tahap perbandingan berpasangan elemen. Perbandingan berpasangan adalah untuk menandai skor prioritas dengan skala 9 poin untuk kontribusi ke $\mathrm{n}$ yang lebih tinggi terhadap hierarki yang lebih rendah terdiri dari $n$ elemen dimana perbandingan dilakukan $\mathrm{n}$ $(n-1) / 2$ kali. Mencari nilai Eigen, bobot relatif (Vektor Prioritas) dari faktor pengambilan keputusan yang diperkirakan.

Tabel 2.1 : Tabel Skala Banding Penilaian Berpasangan 


\begin{tabular}{|c|l|l|}
\hline $\begin{array}{l}\text { Intensit } \\
\text { as } \\
\text { Kepen- } \\
\text { tingan }\end{array}$ & \multicolumn{1}{|c|}{$\begin{array}{c}\text { Definisi } \\
\text { Verbal }\end{array}$} & Penjelasan \\
\hline 1 & $\begin{array}{l}\text { Kedua } \\
\text { elemen sama } \\
\text { pentingnya. }\end{array}$ & $\begin{array}{l}\text { Penilaian } \\
\text { satu elemen } \\
\text { yang } \\
\text { dibandingk } \\
\text { an dengan } \\
\text { elemen } \\
\text { lainnya } \\
\text { adalah } \\
\text { sama. }\end{array}$ \\
\hline 3 & $\begin{array}{l}\text { Satu elemen } \\
\text { lebih lemah } \\
\text { tingkat } \\
\text { kepentingann } \\
\text { ya } \\
\text { dibandingkan } \\
\text { dengan } \\
\text { elemen } \\
\text { lainnya. }\end{array}$ & $\begin{array}{l}\text { sedikit } \\
\text { memihak } \\
\text { pada } \\
\text { sebuah } \\
\text { elemen } \\
\text { dibandingk } \\
\text { an elemen } \\
\text { lainnya. }\end{array}$ \\
\hline
\end{tabular}

\begin{tabular}{|c|c|c|}
\hline 5 & $\begin{array}{l}\text { Satu elemen } \\
\text { lebih esensial } \\
\text { atau } \\
\text { mempunyai } \\
\text { tingkat } \\
\text { kepentingan } \\
\text { yang cukup } \\
\text { kuat } \\
\text { dibandingkan } \\
\text { dengan } \\
\text { elemen } \\
\text { lainnya. }\end{array}$ & $\begin{array}{l}\text { Penilaian } \\
\text { secara kuat } \\
\text { memihak } \\
\text { pada } \\
\text { sebuah } \\
\text { elemen } \\
\text { dibandingk } \\
\text { an elemen } \\
\text { lainnya. }\end{array}$ \\
\hline 7 & $\begin{array}{l}\text { Satu elemen } \\
\text { menunjukkan } \\
\text { tingkat } \\
\text { kepentingan } \\
\text { yang sangat } \\
\text { kuat } \\
\text { dibandingkan } \\
\text { terhadap } \\
\text { elemen } \\
\text { lainnya. }\end{array}$ & $\begin{array}{l}\text { Sebuah } \\
\text { elemen } \\
\text { secara kuat } \\
\text { disukai dan } \\
\text { mendomina } \\
\text { si terhadap } \\
\text { elemen } \\
\text { lainnya. }\end{array}$ \\
\hline 9 & $\begin{array}{l}\text { Slah satu } \\
\text { elemen } \\
\text { menunjukkan } \\
\text { tingkat } \\
\text { kepentingan } \\
\text { yang mutlak } \\
\text { lebih tinggi } \\
\text { terhadap } \\
\text { elemen } \\
\text { lainnya. }\end{array}$ & $\begin{array}{l}\text { Bukti } \\
\text { bahwa } \\
\text { suatu } \\
\text { elemen } \\
\text { wajib ada } \\
\text { dibandingk } \\
\text { an elemen } \\
\text { lainnya. }\end{array}$ \\
\hline $2,4,6,8$ & $\begin{array}{l}\text { Nilai-nilai } \\
\text { tengah } \\
\text { diantara dua } \\
\text { pendapat } \\
\text { yang } \\
\text { berdampinga } \\
\text { n. }\end{array}$ & $\begin{array}{l}\text { Nilai-nilai } \\
\text { yang } \\
\text { diberikan } \\
\text { bila } \\
\text { diperlukan } \\
\text { suatu } \\
\text { kompromi. }\end{array}$ \\
\hline $\begin{array}{l}\text { Kebalika } \\
\text { n dari } \\
\text { nilai di } \\
\text { atas }\end{array}$ & \multicolumn{2}{|c|}{$\begin{array}{l}\text { Jika elemen I memperoleh } \\
\text { salah satu nilai dari tabel } \\
\text { nilai di atas pada saat } \\
\text { dibandingkan dengan } \\
\text { elemen } \mathrm{j} \text {, maka elemen } \mathrm{j} \\
\text { memiliki nilai kebalikannya } \\
\text { bila dibandingkan dengan } \\
\text { nilai i. }\end{array}$} \\
\hline
\end{tabular}

Ini untuk mendapatkan nilai Eigen maksimum dalam perbandingan 
berpasangan dengan rata-rata geometrik dan dengan menormalkan vektor eigen yang diturunkan berdasarkan nilai bobot kemampuan manajerial terhadap faktor kehadiran, kehandalan dan pengetahuan yang akan dihitung sebagai nilai eigen.

$\mathrm{A} \cdot \mathrm{W}=\lambda_{\text {maks }} \cdot \mathrm{W}$

$\Lambda=$ Nilai Eigen

$\mathrm{W}=$ Vektor Eigen (disesuaikan dengan $\lambda$ )

Vektor Eigen yang dihitung adalah dengan mencari nilai consistency Rate yang dihasilkan dari nilai perhitungan matriks acak dari $\mathrm{n} * \mathrm{n}$. Penilaian tingkat konsistensi perbandingan berpasangan mempunyai nilai rasionya kurang dari 0,1 , ini berarti nilai berpasangan matriks perbandingan memiliki konsistensi.

$\mathrm{CR}=\mathrm{CI} / \mathrm{RI}$

CR: Tingkat Konsistensi

CI: Indeks Konsistensi

RI: Indeks Acak

Tabel 2.2 : Tabel Skala Penilaian

\begin{tabular}{|c|c|}
\hline $\begin{array}{c}\text { Skala } \\
\text { Penilaian }\end{array}$ & Keterangan \\
\hline 1 & $\begin{array}{lll}\text { Hanya } & \text { duduk } & \text { dan akan } \\
\text { bekerja } & \text { dengan } & \text { menunggu } \\
\text { perintah } & & \end{array}$ \\
\hline 2 & $\begin{array}{llr}\text { Memiliki inisiatif } & \text { kerja } \\
\text { rendah dan } & \text { selalu } \\
\text { membutuhkan } & \text { stimulasi } \\
\text { supervisor } & & \end{array}$ \\
\hline 3 & $\begin{array}{l}\text { Memiliki inisiatif kerja serta } \\
\text { dapat bekerja dibawah } \\
\text { tekanan namun butuh } \\
\text { stimulasi supervisor }\end{array}$ \\
\hline 4 & $\begin{array}{l}\text { Memiliki inisiatif kerja serta } \\
\text { dapat bekerja dibawah } \\
\text { tekanan dengan tingkat } \\
\text { stimulasi supervisor yang } \\
\text { jarang }\end{array}$ \\
\hline 5 & $\begin{array}{l}\text { Memiliki inisiatif kerja serta } \\
\text { dapat bekerja dibawah } \\
\text { tekanan tanpa stimulasi } \\
\text { supervisor }\end{array}$ \\
\hline
\end{tabular}

Tabel 2.3 : Test Kriteria Terhadap Konsistensi Ratio

\begin{tabular}{|l|l|}
\hline \multicolumn{1}{|c|}{ Test Kriteria } & \multicolumn{1}{c|}{ Keterangan } \\
\hline $\mathrm{CR}<0.1$ & Layak \\
$0.1 \leq \mathrm{CR} \leq 0.2$ & Toleransi \\
$0.2 \leq \mathrm{CR}$ & Ditolak \\
\hline
\end{tabular}

\section{Langkah 4: Sintesis bobot relatif}

Sintesis terakhir dari elemen pengambilan keputusan adalah dibuat untuk mendapatkan nilai bobot yang komprehensif untuk alternatif target pengujian. Dengan melakukan survey secara acak terhadap 6 orang yang terlibat dalam penilaian dari keseluruhan 27 responden akan menunjukkan hasil nilai $\mathrm{CR}<0.1$ atau lebih. Nilai CR nilai kurang dari 0,1 pada semua unit penilaian menunjukkan nilai harus dipercaya / mempunyai kepentingan dan prioritas relatif untuk masing-masing faktor penilaian.

Tabel 2.4 Skala Penilaian Kinerja Kehadiran

\begin{tabular}{|c|c|}
\hline $\begin{array}{c}\text { Skala } \\
\text { Penilaian }\end{array}$ & Keterangan \\
\hline 1 & Kehadiran kerja $<25 \%$ \\
\hline 2 & Kehadiran kerja $<40 \%$ \\
\hline 3 & Kehadiran kerja $<50 \%$ \\
\hline 4 & Kehadiran kerja $<75 \%$ \\
\hline 5 & Kehadiran kerja $\geq 75 \%$ \\
\hline
\end{tabular}

Tabel 2.5 Skala Penilaian Kinerja Pengetahuan

\begin{tabular}{|c|l|}
\hline Skala & \multicolumn{1}{|c|}{ Keterangan } \\
\hline 1 & $\begin{array}{l}\text { Sulit mengerti tugas dan arahan } \\
\text { serta kurang adannya kemauan } \\
\text { belajar }\end{array}$ \\
\hline 2 & $\begin{array}{l}\text { Lambat mengerti dan butuh } \\
\text { latihan }\end{array}$ \\
\hline 3 & $\begin{array}{l}\text { Mampu mengerti tugas yang } \\
\text { diberikan dengan arahan dan } \\
\text { cocok praktek }\end{array}$ \\
\hline 4 & $\begin{array}{l}\text { Mampu mengerti tugas yang } \\
\text { diberikan dengan arahan }\end{array}$ \\
\hline 5 & $\begin{array}{l}\text { Mampu mengerti tugas yang } \\
\text { diberikan tanpa arahan }\end{array}$ \\
\hline
\end{tabular}




\section{Landasan Teori}

Pengertian Manajerial menurut Maria, 2018, manajerial didefinisikan sebagai penerapan teori ekonomi dan berbagai alat dalam ilmu pengambilan keputusan (decision sciences) untuk memecahkan berbagai permasalahan manajerial di dalam suatu organisasi dengan cara yang paling efisien.

Dalam suatu badan usaha, peranan sumber daya manusia (SDM) dalam sebuah organisasi begitu penting dan menentukan. Oleh sebab itu, maka diperlukan sebuah pengelolaan yang dilakukan secara sistematis, terencana dan terpola agar tujuan yang sangat diinginkan baik untuk masa sekarang atau untuk masa depan dapat dicapai secara optimal ( (Hamid, 2014) p. 28). Juga menurut pendapat Rivai dalam ( (Hamid, 2014) p. 30)., sumber daya manusia (SDM) merupakan sebuah masalah perusahaan yang paling kompleks, karena beberapa sebab, yaitu : menyebabkan sumber daya lain berfungsi, menciptakan efisiensi, efektivitas, dan juga peningkatan produktivitas perusahaan.

Menurut Penelitian (Ilhami, 2017), penggunaan metode Analytic Hierarchy Process (AHP) untuk meneliti kinerja manajerial sangat tepat guna membuat keputusan dan merekomendasikan kerangka perencanaan penilaian kinerja untuk junior analis menggunakan metode Rating-Scale untuk melakukan promosi jabatan. Kriteria utama yang diperoleh dari penelitian ini adalah kehadiran, pencapaian target kerja, ketelitian kerja, proaktif, empati, kerjasama (tim/organisasi), pemikiran analitis, dan fleksibilitas.

Menurut (Miftahuddin, 2017), terdapat 3 faktor yang mempengaruhi kinerja karyawan, 3 faktor tersebut adalah karakteristik pribadi, kompetensi kerja, dan sifat umum.

Menurut (Pardosi, 2013. ), perlu diterapkan penilaian kinerja yang lebih objektif dengan tujuan mengetahui gambaran kinerja karyawan secara objektif. Pengukuran kinerja karyawan dilakukan terhadap level manajer dengan menggunakan AHP. Dari hasil penelitian, diperoleh prioritas variabel kinerja adalah kompetensi kerja. Prioritas subvariabel adalah kepemimpinan, keterampilan komunikatif dan tingkat komitmen bekerja.

Dari penelitian (Saif, 2013) disimpulkan bahwa faktor penting untuk kompetensi berdasarkan analisis pekerjaan. Hasil mengungkapkan bahwa keterampilan dan kinerja sangat terkait, yang menunjukkan bahwa kedua faktor ini penting untuk analisis pekerjaan berbasis kompetensi. Hasil juga mencerminkan bahwa pengetahuan dan analisis pekerjaan juga terkait satu sama lain dan bahwa kedua variabel ini bergantung dan tidak dapat ditangani secara terpisah.

Menurut (Pambagio, 2013), dalam penelitiannya, proses rekrutmen, proses seleksi, dan kompetensi karyawan di secara signifikan dapat turut berperan serta dalam meningkatkan kinerja karyawan.

Dalam penelitian (Palupi, 2018), AHP adalah sebuah metode yang tepat untuk mendapatkan solusi terbaik dari beberapa alternatif solusi yang ada, dengan berdasar pada memanfaatkan pairwaise comparison sebagai dasar dalam menentukan pilihan. Adapun kriteria yang digunakan dalam metode ini adalah enam kriteria yaitu Pendidikan Terakhir, Pengalaman Kerja, Umur, Status, Skill (kemampuan) Operasi komputer dan Fasih Berbahasa Inggris. Dengan memadukan antara data kriteria dan bobot yang dimaksudkan dengan data-data dari kriteria penilaian pada karyawan yang ada, sistem ini akan dapat menghasilkan suatu peringkat atau rangking atau nilai akhir dari masing-masing lokasi. Dimana semakin besar nilai akhir yang didapatkan, maka itu berarti semakin sesuai pula dengan kriteria yang ada untuk penerimaan karyawan. Sehingga diharapkan makin memudahkan perusahaan dalam memilih dan mendapatkan karyawan sesuai dengan kriteria yang diinginkan perusahaan.

Menurut (Turban, 2011), Sistem Pendukung Keputusan dan Intelijen Bisnis menyediakan satu-satunya panduan yang komprehensif dan terkini untuk teknologi sistem pendukung manajemen revolusioner saat ini, dan menunjukkan bagaimana mereka dapat digunakan untuk pengambilan keputusan yang lebih baik.

Menurut (Arifin, 2013), Metode AHP dapat digunakan sebagai alat bantu untuk pengambilan keputusan dalam permasalahan penilaian kinerja karyawan. 


\section{HASIL DAN PEMBAHASAN}

Nilai CR dari kemampuan manajerial adalah 0,0379 dan derajat kepentingan relatif serta prioritas diantara faktor yang dievaluasi / dianalisis dengan urutan kehadiran $(0,6615)$, pengetahuan $(0,1705)$ dan kerjasama (0,1679). Penilai mempertimbangkan hasil prestasi kerja terhadap kehadiran karyawan merupakan faktor yang paling penting untuk aktifitas kemampuan manajerial. Nilai skor total rata-rata ke 27 responden yang didapatkan dari aspek manajerial terhadap faktor kehadiran, pengetahuan dan kerjasama sebesar 4.389. Nilai prestasi kerja standar yang diinginkan sebesar 3.389, dimana nilai skor total lebih tinggi dari nilai prestasi yang ditetapkan dan ini menunjukkan bahwa aspek manajerial berpengaruh secara langsung pada ketiga faktor tersebut. Skor total dari penilaian kinerja karyawan lebih tinggi dari nilai standar yang ditetapkan membuktikan bahwa penilaian dari ketigas faktor tersebut mempunyai dampak yang positif terhadap besarnya pemberian insentif kepada

\begin{tabular}{|c|c|c|c|c|c|c|c|c|}
\hline No. & Nama Pegawai & Jumlah & skor & skor & skor & total & prestasi & kenaikan \\
\hline & & Produk (Unit)' & kehadiran & keandalan & pengetahuan & skor & kerja standar & prestasi (96) \\
\hline 1 & Abdul Kahar & 2790 & 0.110 & 0.581 & 0.065 & 4.399 & 3.297 & 33.411 \\
\hline 2 & Ahmad Jazuli & 2768 & 0.110 & 0.726 & 0.065 & 4.231 & 3.297 & 28.328 \\
\hline 3 & Ahmad Khotib & 832 & 0.110 & 0.726 & 0.087 & 4.566 & 3.297 & 38.475 \\
\hline 4 & Aryo Utoyo & 980 & 0.110 & 0.726 & 0.108 & 3.961 & 3.297 & 20.152 \\
\hline 5 & Bambang Kisworo & 894 & 0.110 & 0.726 & 0.087 & 3.940 & 3.297 & 19.495 \\
\hline 6 & Cahyo Utomo & 760 & 0.110 & 0.726 & 0.087 & 4.566 & 3.297 & 38.475 \\
\hline 7 & Edi Kurnianto & 1702 & 0.110 & 0.581 & 0.087 & 4.420 & 3.297 & 34.068 \\
\hline 8 & Fauzi Rachmat & 1550 & 0.110 & 0.726 & 0.087 & 4.893 & 3.297 & 48.408 \\
\hline 9 & Haris Mulyono & 934 & 0.110 & 0.726 & 0.087 & 4.253 & 3.297 & 28.985 \\
\hline 10 & Hidayatullah & 853 & 0.110 & 0.726 & 0.087 & 4.480 & 3.297 & 35.886 \\
\hline 11 & Joko Susilo & 800 & 0.110 & 0.726 & 0.108 & 4.587 & 3.297 & 39.132 \\
\hline 12 & Krisna Aliyuddin & 670 & 0.110 & 0.726 & 0.087 & 4.153 & 3.297 & 25.954 \\
\hline 13 & Lukman & 902 & 0.110 & 0.726 & 0.065 & 4.146 & 3.297 & 25.739 \\
\hline 14 & Mardianto & 1300 & 0.110 & 0.726 & 0.087 & 4.566 & 3.297 & 38.475 \\
\hline 15 & M. Amirul & 800 & 0.110 & 0.726 & 0.087 & 4.253 & 3.297 & 28.985 \\
\hline 16 & M. Chairul Soleh & 1310 & 0.110 & 0.726 & 0.087 & 4.253 & 3.297 & 28.985 \\
\hline 17 & M. Rozali & 2040 & 0.110 & 0.581 & 0.087 & 4.520 & 3.297 & 37.099 \\
\hline 18 & Muzammil Ahmad & 1050 & 0.110 & 0.581 & 0.087 & 4.007 & 3.297 & 21.547 \\
\hline 19 & Ngatijo & 2768 & 0.110 & 0.726 & 0.087 & 4.253 & 3.297 & 28.985 \\
\hline 20 & Ngizathul Rahim & 2752 & 0.110 & 0.726 & 0.087 & 4.167 & 3.297 & 26.396 \\
\hline 21 & Samijan & 800 & 0.110 & 0.726 & 0.087 & 4.566 & 3.297 & 38.475 \\
\hline 22 & Samsuri & 773 & 0.110 & 0.726 & 0.087 & 4.566 & 3.297 & 38.475 \\
\hline 23 & SriWidodo & 1900 & 0.110 & 0.726 & 0.087 & 4.480 & 3.297 & 35.886 \\
\hline 24 & Subroto & 856 & 0.110 & 0.726 & 0.087 & 4.566 & 3.297 & 38.475 \\
\hline 25 & Sramsudin & 870 & 0.110 & 0.726 & 0.087 & 4.566 & 3.297 & 38.475 \\
\hline 26 & Waluyo & 1280 & 0.110 & 0.726 & 0.087 & 4.480 & 3.297 & 35.886 \\
\hline 27 & Zubar & 2343 & 0.110 & 0.726 & 0.087 & 4.665 & 3.297 & 41.506 \\
\hline
\end{tabular}

karyawan. Pemahaman ini dapat diartikan bahwa kepentingan karyawan terhadap kemampuan manajerial sangatlah penting untuk menentukan besarnya pendapatan yang harus diterima oleh setiap karyawan

\begin{tabular}{|c|c|c|c|c|}
\hline $\begin{array}{l}\mathrm{N} \\
\mathrm{o}\end{array}$ & $\begin{array}{l}\text { Nama } \\
\text { Pegawai }\end{array}$ & Target & Kehadiran & $\begin{array}{l}\text { Persent } \\
\text { ase }\end{array}$ \\
\hline 1 & $\begin{array}{l}\text { Abdul } \\
\text { Kahar }\end{array}$ & 26 & 26 & 100,00 \\
\hline
\end{tabular}

berdasarkan prestasi kerja atau besarnya output produksi yang dihasilkan.

Formula tersebut dimasukkan dalam kolom nilai kehadiran yang telah dibuat. Kemudian buat kolom target kehadiran dan kehadiran, bandingkan jumlah kehadiran karyawan dalam kolom kehadiran dengan target hadir dalam kolom target kehadiran. Kemudian hasilnya masukkan ke dalam kolom persentase kehadiran seperti di bawah ini dengan menggunakan perwakilan karyawan bernama Abdul Kahar sebagai contoh :

Tabel 3.1 : Kemampuan Kehadiran karyawan Abdul Kahar Dimasukkan Dalam Kolom Kehadiran

Tabel 3.2 : Nilai Kehadiran Yang Muncul Berdasarkan Persentase Kehadiran Karyawan Abdul Kahar

\begin{tabular}{|c|c|c|}
\hline No. & $\begin{array}{c}\text { Nama } \\
\text { Pegawai }\end{array}$ & $\begin{array}{c}\text { Nilai } \\
\text { Kehadiran }\end{array}$ \\
\hline 1 & Abdul Kahar & 5 \\
\hline
\end{tabular}

Setelah hasil perbandingan dimasukkan ke dalam kolom persentase (\%) kehadiran, maka secara otomatis nilai akan keluar pada kolom nilai kehadiran. Persentase kehadiran Abdul Kahar adalah sebesar $100 \%$, maka nilai yang keluar adalah nilai 5, karena $100 \%$ > $75 \%$. (perhitungan dan seterusnya).

Tabel 3.3 Hasil Perhitungan Kemampuan manajerial 
Berikut ini adalah rancangan use case diagram untuk pengukuran penilaian kinerja karyawan.

Gambar 3.1 : Rancangan Use Case Diagram pengukuran penilaian Kinerja Karyawan

\section{KESIMPULAN}

Penelitian ini dimaksudkan untuk meneliti hal-hal yang penting pada indikator kemampuan manajerial terhadap faktor pendukung dari masing-masing kriteria seperti kehadiran $(0,6615)$, pengetahuan $(0,1705)$ dan kerjasama $(0,1679)$. Nilai skor total rata-rata ke 27 responden yang didapatkan dari aspek manajerial terhadap faktor kehadiran, pengetahuan dan kerjasama sebesar 4.389. Nilai prestasi kerja standar yang diinginkan sebesar 3.389, dimana nilai skor total lebih tinggi dari nilai prestasi. Sebagai hasil penelitian dari kemampuan manajerial terhadap faktor kehadiran, pengetahuan dan kerjasama secara analisis berdampak langsung terhadap peningkatan nilai prestasi kerja rata-rata $33.117 \%$. Hal tersebut menegaskan bahwa kemampuan manajerial mempunyai skala prioritas dalam menentukan nilai prestasi kerja yang diinginkan sehingga pihak manajemen dapat memberikan besarnya kenaikan prestasi yang sesuai dengan kemampuan karyawan dalam menyelesaikan pekerjaannya.

\section{REFERENSI}

Arifin, S. L. (2013). Pengambilan Keputusan Untuk Penilaian Kinerja Menngunakan

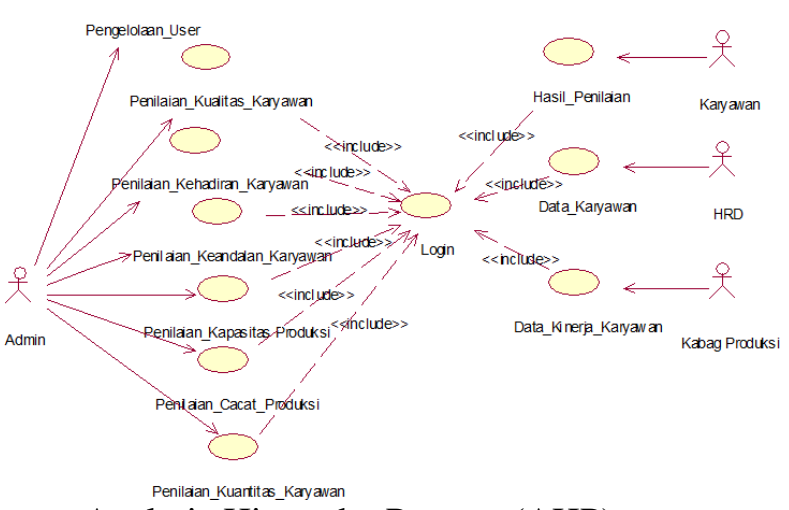

Analytic Hierarchy Process (AHP). Prosiding Seminar Nasional Penelitian, Pendidikan dan Penerapan MIPA. Fakultas MIPA, Universitas Negeri Yogyakarta.

Hamid, S. ( 2014). Manajemen Sumber Daya Manusia Lanjutan . Yogyakarta: CV. Budi Utama.

Ilhami, R. d. (2017). Penilaian Kinerja Karyawan Dengan Metode AHP dan Rating Scale. Optimasi Sistem Industri.16 (2), 150 - 157.

Miftahuddin, M. d. (2017). Penentuan Strategi Untuk Meningkatkan Kinerja Karyawan Di BNI Kantor Cabang Semarang Dengan Menggunakan Metode AHP (Analytical Hierarchy Process). . Jurnal Dinamika Teknik. 10 (2):, 1-8.

Palupi, S. L. (2018). Sistem Pendukung Keputusan Pemerimaan Karyawan pada PT. Suryaintan Tri Lestari dengan Metode AHP Berbasis Web. Sebatik, 11(1), pp. 25-31.

Pambagio, N. S. (2013). Pengaruh proses rekrutmen, proses seleksi, dan kompetensi karyawan terhadap kinerja karyawan. . Jurnal Administrasi Bisnis, , $1-7$.

Pardosi, J. M. ( 2013. ). Pengukuran Kinerja Dengan Menggunakan Integrasi 360 Feedback dan AHP Di PT. S. $e$ Jurnal Teknik Industri USU. 3 (2):, 1-7.

Saif, N. d. (2013). Competency Based Job Analysis. International Journal of Academic Research in Accounting. 3 (1): . 105-111. 
Turban, E. S. (2011). Decision Support and Business Intelligence Systems, Edisi 9.

In P. E. Inc. 